\title{
Analisis Penjadwalan Irigasi pada Budidaya Tanaman Talas Pratama (Colocasia esculenta (L). Schott var. Pratama) Menggunakan CROPWAT 8.0
}

\author{
Irrigation Schedulling Analysis on the Cultivation of Pratama Taro (Colocasia esculenta (L). Schott Var. Pratama) \\ Using CROPWAT 8.0
}

\author{
Leni Nurliani ${ }^{1 *}$, Sophia Dwiratna², Boy Macklin Pareira Prawiranegara² \\ ${ }^{1}$ Program Studi Teknik Pertanian, Universitas Padjadjaran \\ ${ }^{2}$ Departemen Teknik Pertanian dan Biosistem, Universitas Padjadjaran \\ Jalan Raya Bandung - Sumedang KM.21, Jatinangor 45362, Jawa Barat \\ *Email: leninurliani.In@gmail.com
}

Diterima: 7 Desember 2018; Disetujui: 12 November 2019

\begin{abstract}
ABSTRAK
Tanaman Talas (Colocasia esculenta (L). Schott) merupakan salah satu bahan pangan lokal yang dapat digunakan sebagai penunjang swasembada pangan nasional. Salah satu cara untuk menunjang pertumbuhan dan perkembangan yang baik dilakukan kajian analisis penjadwalan irigasi yang tepat. Penelitian ini dilakukan untuk mengkaji penjadwalan irigasi pada budidaya Talas Pratama (Colocasia esculenta (L). Schott var. Pratama) di lahan penelitian menggunakan aplikasi Cropwat 8.0 untuk mengoptimalkan ketersediaan air. Metode yang digunakan dalam penelitian ini adalah deskriptif analisis yaitu dengan mengumpulkan data-data yang dibutuhkan serta menganalisis dan menggambarkan besarnya kebutuhan air dan interval pemberian air irigasi dengan menggunakan Software Cropwat 8.0 yang dikembangkan oleh FAO. Interval waktu yang digunakan yaitu berdasarkan setiap tahap pertumbuhan talas dengan jumlah air yang diberikan hingga memenuhi kapasitas lapang pada lahan penelitian. Hasil penelitian ini menunjukan bahwa jumlah kebutuhan air tanaman Talas Pratama (Colocasia esculenta (L). Schott var. Pratama) berdasarkan Cropwat 8.0 yaitu sebesar $1093,9 \mathrm{~mm}$ sedangkan kebutuhan air irihasi untuk interval 3 hari, dan $1.853 .400 \mathrm{~mm}$ untuk interval 4 hari adalah 1.605 .150 pada lahan seluas 1500 $\mathrm{m}^{2}$.
\end{abstract}

Kata kunci: Penjadwalan Irigasi; Cropwat 8.0; Neraca Air; Talas Pratama

\begin{abstract}
Taro (Colocasia esculenta $(L)$ Schott) is one of the local foodstuffs that can be used to support national food self-sufficiency. One way to support good growth and development is an accurate irrigation scheduling analysis. The research was conducted to assess irrigation scheduling of Pratama Taro (Colocasia esculenta $(\mathrm{L})$ Schott var Pratama) in the field of research using Cropwat 8.0 to optimize water availability. The method used in this research was descriptive analysis that is by collecting the required data also analyze and describe the amount of water needs and interval of irrigation watering by using Software Cropwat 8.0 developed by FAO because easy to use and more efficient. The time interval used was based on every stage of taro growth with the amount of water provided to meet the field capacity on the research field. The results of this study indicated that the amount of irrigation water demand in the field of research for Pratama Taro (Colocasia esculenta (L) Schott var Pratama) based on Cropwat 8.0 was 1.482 .960 liter for 3 days interval, 1.283 .760 liter for 4 days interval.
\end{abstract}

Keywords: Irrigation Scheduling; Cropwat 8.0; Water Balance; Pratama Taro

\section{PENDAHULUAN}

Tanaman talas atau yang dikenal dengan nama latin Colocasia esculenta (L). Schott ini, merupakan jenis tumbuhan yang cukup digemari oleh masyarakat di berbagai belahan negara. Tidak hanya masyarakat di Indonesia saja yang menjadikan talas sebagai alternatif bahan pangan untuk pengganti nasi, namun juga dibeberapa negara seperti, Thailand, Brazil dan Hawai Amerika Serikat, talas dijadikan sebagai bahan dasar untuk memenuhi kebutuhan pangan. Umbi talas adalah satu diantara beberapa komoditas umbi-umbian yang dapat dijadikan sebagai alternatif selain beras yang bersifat sehat dan aman terutama bagi penderita penyakit diabetes dan bagi orang yang melakukan program diet. Tingkat keamanan dari umbi talas tersebut terletak pada rendahnya kandungan karbohidrat sebesar $22,25 \%$, dibandingkan dengan kandungan karbohidrat dalam beras sebesar 67,89 \% (Iskandar, 2018; Sudomo \& Hani, 2014). Berdasarkan pada tingginya nilai pemanfaatan tersebut, mengakibatkan permintaan umbi talas mengalami peningkatan. Akan tetapi peningkatan tersebut belum dapat dipenuhi sebagai akibat dari rendahnya tingkat produktivitas umbi. Hal tersebut sangat dengan tanaman talas yang hanya ditanam satu kali dalam satu tahun, yaitu pada awal musim penghujan (Sudomo \& Hani, 2014).

Salah satu talas terbaru yang mulai masif dibudidayakan adalah Talas varietas Pratama.Talas Pratama ini baru dikembangkan pada pertengahan tahun 2016. Talas pratama ada berawal dari Pusat Penelitian Bioteknologi Lembaga IImu Pengetahuan Indonesia (LIPI) di Cibinong, Bogor. Setelah penelitian yang dilakukan lebih kurang 13 tahun, pada tahun 2016 talas varietas unggul tersebut diresmikan dengan nama Talas Varietas Pratama. 
Pratama yang ada pada nama varietas Pratama merupakan singkatan dari ketiga peneliti yang telah melakukan seleksi terhadap talas.

Keberhasilan suatu kegiatan pertanian sangat ditentukan oleh pertimbangan antara jumlah air yang tersedia di lahan dengan jumlah air yang dibutuhkan tanaman selama masa pertumbuhannya. Jumlah air yang tersedia pada suatu lahan pertanian dapat dilihat dari kondisi curah hujan, sedangkan jumlah air yang dibutuhkan oleh tanaman dapat digambarkan dengan jumlah air yang dibutuhkan oleh tanaman dapat digambarkan dengan jumlah air yang dibutuhkan untuk evapotranspirasi (S. Dwiratna, Bafdal, Asdak, \& Carsono, 2018; Fuadi, Tarigan, Barat, \& Barat, 2016; Suryadi, Kendarto, Sistanto, Ruswandi, \& Dwiratna, 2018). Berdasarkan kondisi tersebut diperlukan suatu metode untuk menganalisis kebutuhan air dan penjadwalan irigasi yang sesuai sesuai kondisi lapangan dan tanaman Talas Pratama tersebut. Salah satu cara menganalisis kebutuhan air irigasi adalah dengan menggunakan software Cropwat 8.0 for Windows. Cropwat 8.0 merupakan aplikasi decision support system yang dikembangkan oleh Land and Water Development Division FAO pada tahun 1991 yang dapat digunakan dalam menghitung kebutuhan air irigasi satu atau beberapa tanaman dalam satu hamparan untuk setiap bulan, hingga menyusun simulasi atau rekomendasi penjadwalan irigasi (Savva \& Frenken, 2002). Penelitian ini dilakukan untuk mengkaji penjadwalan irigasi pada budidaya Talas Pratama (Colocasia esculenta (L). Schott var. Pratama) di lahan penelitian menggunakan aplikasi Cropwat 8.0 untuk mengoptimalkan ketersediaan air.

\section{METODE PENELITIAN}

Penelitian ini dilakukan dengan metode deskriptif analisis yaitu dengan cara mengumpulkan data-data yang dibutuhkan untuk perhitungan kebutuhan air dan interval irigasi. Serta menganalisis dan menggambarkan besarnya kebutuhan air dan interval pemberian air irigasi dengan menggunakan Cropwat 8.0 dengan masukan data 10 (sepuluh) tahun terakhir berupa data klimatologi meliputi suhu, kelembaban, kecepatan angin, lama penyinaran dan curah hujan serta data tanaman Talas Pratama dan data lahan.

\section{Analisis Data Klimatologi}

Analisis data klimatologi 10 tahun terakhir dari tahun 2008-2017, meliputi data suhu, kelembaban, kecepatan angin, dan lama penyinaran serta curah hujan.

\section{Analisis Nilai Evapotranspirasi Potensial}

Perhitungan ETo dengan Metode Penman-Monteith (FAO NO 56. Irrigation and Drainage) dengan persamaan berikut (Allen, Pereira, Raes, \& Smith, 1998; Sophia Dwiratna, Bafdal, Asdak, \& Carsono, 2018a):

$$
\mathrm{ET}_{\mathrm{o}}=\frac{0.408 \Delta(R n-G)+\gamma \frac{900}{T+273} u_{2}\left(e_{s}-e_{a}\right)}{\Delta+\gamma\left(1+0.34 u_{2}\right)}
$$

Keterangan :

ETo = Evapotranspirasi acuan ( $\mathrm{mm} /$ hari),

$\mathrm{Rn}=$ Radiasi netto pada permukaan tanaman (MJ $/ \mathrm{m}^{2} /$ hari),

$\mathrm{G}=$ Kerapatan panas terus-menerus pada tanah $\left(\mathrm{MJ} / \mathrm{m}^{2} /\right.$ hari),
$\mathrm{T}=$ Temperatur harian rata-rata pada ketinggian $2 \mathrm{~m}$ $\left({ }^{\circ} \mathrm{C}\right)$,

$\mathrm{u}_{2}=$ Kecepatan angin pada ketinggian $2 \mathrm{~m}(\mathrm{~m} / \mathrm{s})$,

$\mathrm{e}_{\mathrm{s}} \quad=$ Tekanan uap jenuh $(\mathrm{kPa})$

$\mathrm{e}_{\mathrm{a}} \quad=$ Tekanan uap aktual $(\mathrm{kPa})$,

$\Delta \quad=$ Kurva kemiringan tekanan uap $\left(\mathrm{kPa} /{ }^{\circ} \mathrm{C}\right)$,

$\gamma \quad=$ Konstanta psychrometric $\left(\mathrm{kPa} /{ }^{\circ} \mathrm{C}\right)$.

\section{Analisis Curah Hujan Efektif}

Curah hujan bulanan efektif; Menggunakan metode USDA Soil Conservation Service. Dimana persamaan yang digunakan adalah sebagai berikut (Allen et al., 1998; Savva \& Frenken, 2002):

untuk Pmean $<250 \mathrm{~mm}$

Pef $=$ Pmean $\times(125-0,2 \times$ Pmean $) / 125$

untuk Pmean $>250$

Pef $=125+(0,1 \times$ Pmean $) \mathrm{mm}$

Keterangan:

Pef $\quad=$ Hujan efektif $(\mathrm{mm})$

Pmean = Rata-rata hujan bulanan $(\mathrm{mm})$

\section{Analisis Data Tanaman dan Tanah}

- Data tanaman berupa nila koefisien tanaman (Kc), lamanya hari tumbuh dalam setiap fase, kedalaman akar, tinggi tanaman, yield respon factor $(K y)$ dan critical depletion.

- Data tanah berupa tekstur tanah, TAM (Total Available Soil Moisture Content) / total lengas tanah tersedia, Initial Soil Moisture Depletion (\%TAM), Maximum Rooting Depth (kedalaman akar maksimum) dan maximum rain.infiltration rate (laju infiltrasi maksimum).

\section{Analisis Kebutuhan Air Irigasi}

Kebutuhan air irigasi dihitung dengan menggunakan persamaan berikut (Abdalla et al., 2015; Savva \& Frenken, 2002):

$\operatorname{IRg}=\frac{I R n}{E}$

Keterangan:

$\mathrm{IRg}=$ Kebutuhan irigasi gross $(\mathrm{mm})$

$\mathrm{IRn}=$ Kebutuhan irigasi netto $(\mathrm{mm})$

$\mathrm{E} \quad=$ Efisiensi pemberian air (desimal)

Sedangkan untuk irigasi netto dapat dihitung dengan menggunakan persamaan sebagai berikut (Abdalla, Mustafa, \& Fadlallmula, 2008; Erkossa, Haileslassie, \& MacAlister, 2014; Welde \& Gebremariam, 2016):

$\mathrm{IRn}=\mathrm{ETC}-\mathrm{CH}_{\mathrm{ef}}$

Keterangan:

$\mathrm{IRn}=$ Kebutuhan irigasi netto $(\mathrm{mm})$

$\mathrm{ETc}=$ Evapotranspirasi Tanaman

$\mathrm{CH}_{\text {eff }}=$ Curah Hujan Efektif $(\mathrm{mm})$

\section{Penjadwalan Irigasi}

- Timing option, yang diberikan dengan kapan irigasi diberikan. Pada kategori ini digunakan option 4 (Interval at fixed interval per stage) dimana irigasi diberikan dengan selang interval 3 dan 4 hari pada setiap 
pertumbuhan, pemilihan interval disesuaikan dengan kondisi petani.

Application option yang berkaitan dengan berapa banyak air yang diberikan setiap kali pemberian. Pada kategori ini digunakan option 2 (refill soil to field capacity) dimana jumlah air irigasi setiap aplikasi konstan hingga kadar air memenuhi kapasitas lapang dilahan.

\section{HASIL DAN PEMBAHASAN}

\section{Kondisi Lahan Penelitian}

Waaida Farm merupakan salah satu perusahaan yang bergerak dibidang pertanian. Waaida Farm terletak di Desa Pamulihan, Kecamatan Pamulihan, Kabupaten Sumedang. Lahan di Desa Pamulihan umumnya digunakan untuk bercocok tanam. Komoditas pertanian yang ada di wilayah Desa Pamulihan khususnya Dusun Lembang cukup bervariasi. Di wilayah ini pola tanam yang digunakan yaitu monokultur dan tumpang sari. Komoditas yang mulai massif dibudidayakan adalah Talas varietas terbaru yaitu Talas Pratama. Luas lahan yang digunakan untuk budidaya Talas ini mecapai $9 \mathrm{Ha}$ yang terbagi menjadi beberapa blok. Talas ini biasanya mulai ditanam diawal musim hujan yaitu pada bulan Oktober dan ditanam hingga usia 7 bulan yang kemudian dapat dipanen. Irigasi yang dilakukan di Waaida Farm menggunakan irigasi permukaan dengan bebera sumber air, diantaranya adalah dari sumber mata air dan air yang berasal dari embung-embung yang sengaja dibuat untuk menjadi salah satu langkah konservasi air.

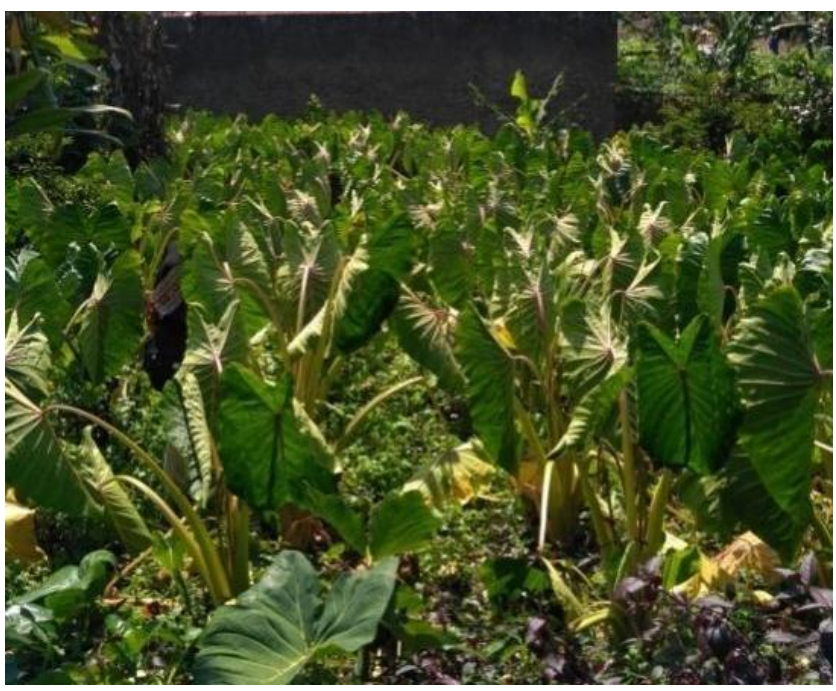

Gambar 1. Kondisi Lahan budidaya Talas Pratama

\section{Analisis Evapotranspirasi Potensial}

Data klimatologi yang digunakan dalam penelitian ini adalah data 10 tahun terakhir sebagai input awal untuk software Cropwat 8.0 dalam menghitung nilai Evapotranspirasi Potensial (ETo) yaitu berupa suhu ratarata, kelembaban udara, kecepatan angin, lama penyinaran matahari, dan curah hujan rata-rata bulanan. Data klimatologi ini sangat bermanfaat dalam proses budidaya tanaman karena petumbungan dan perkembangan tanaman bergantung pada keadaan iklim suatu lingkungan. Perhitungan evapotranspirasi potensial (ETo) pada software Cropwat 8.0 for windows adalah menggunakan metode Penman-Monteithtercantum pada persamaan 1.

Gambar 2 menunjukkan bahwa nilai ETo pada setiap bulannya memiliki nilai yang berbeda-beda berkisar antara $3,12 \mathrm{~mm} /$ hari hingga $4,19 \mathrm{~mm} /$ hari. Nilai ETo ini sendiri dipengaruhi oleh faktor iklim berupa suhu rata-rata, kelembaban udara, kecepatan angin dan lama penyinaran matahari.

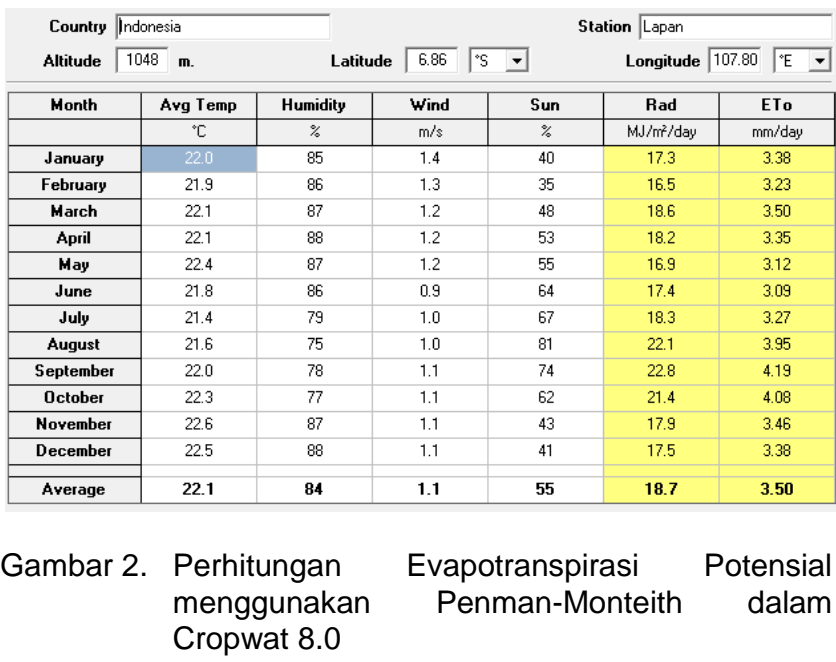

Pengaruh radiasi panas matahari terhadap evapotraspirasi adalah melalui proses fotosintesis, dimana tanaman memerlukan sirkulasi air melalui sistem akarbatang-daun. Sirkulasi ini dapat dipercepat dengan meningkatkannya jumlah radiasi panas matahari terhadap vegetasi yang bersangkutan. Pengaruh suhu terhadap evapotraspirasi berkaitan dengan intensitas dan panjang waktu dari radiasi matahari. Pengaruh angin terhadap evapotrasnpirasi adalah melalui berpindahnya uap air dari pori-pori daun keluar. Semakin besar kecepatan angin maka laju evapotranspirasi pun semakin tinggi.

\section{Analisis Curah Hujan}

Salah satu dari faktor yang mempengaruhi nilai evapotranspirasii potensial untuk analisis data kebutuhan air adalah curah hujan. Berdasarkan data klimatologi Lapan Sumedang 10 tahun terakhir $(2008-2017)$ rata-rata total curah hujan yang terjadi yaitu $195,6839 \mathrm{~mm}$. Dapat dilihat dari Gambar 3. bahwa puncak musim hujan terjadi pada bulan Maret sebesar $366,7 \mathrm{~mm} /$ bulan, sedangkan curah hujan terkecil terjadi pada bulan Agustus sebesar 42,3 $\mathrm{mm} /$ bulan. Terlihat bahwa nilai hujan efektif lebih kecil dibandingan curah hujan rata-rata bulanan, karena hujan efektif merupakan jumlah dari sebagian nilai curah hujan yag daat dimanfaatkan oleh tanaman. Jumlah kebutuhan air memiliki hubungan yang erat dengan evapotranspirasi tanaman (ETc) dan curah hujan $(\mathrm{CH})$ efektif. Jika jumlah $\mathrm{CH}$ efektif lebih besar dari evapotranspirasi tanaman, maka kebutuhan air tercukupi. Sebaliknya, jika jumlah curah hujan lebih rendah dari evapotranspirasi tanaman, maka kebutuhan air tidak tercukupi (Sophia Dwiratna, Nawawi, \& Asdak, 2013).

Besarnya curah hujan yang tidak merata sepanjang tahun disebabkan karena dikenal adanya bulan kering dan bulan basah. Berdasarkan tipe iklim Oldeman, bulan kering (BK) merupakan $\mathrm{CH}<100 \mathrm{~mm}$ sedangkan bulan basah (BS) adalah suatu bulan yang $\mathrm{CH}>100 \mathrm{~mm}$. Berdasarkan olahan data curah hujan bulanan selama 10 tahun terakhir, BK terjadi berturut-turut selama 4 bulan, dari bulan Juni sampai dengan September, sedangkan untuk BS terjadi pada bulan Januari, Februari, Maret, April, Mei, Oktober, 
November dan Desember. Berdasarkan data tersebut, klasifikasi tipe iklim menurut Oldeman rata-rata curah hujan bulanan termasuk kedalam tipe iklim B3 karena memiliki 8 bulan basah dan 4 bulan kering (Sophia Dwiratna, Suryadi, \& Kamaratih, 2016).

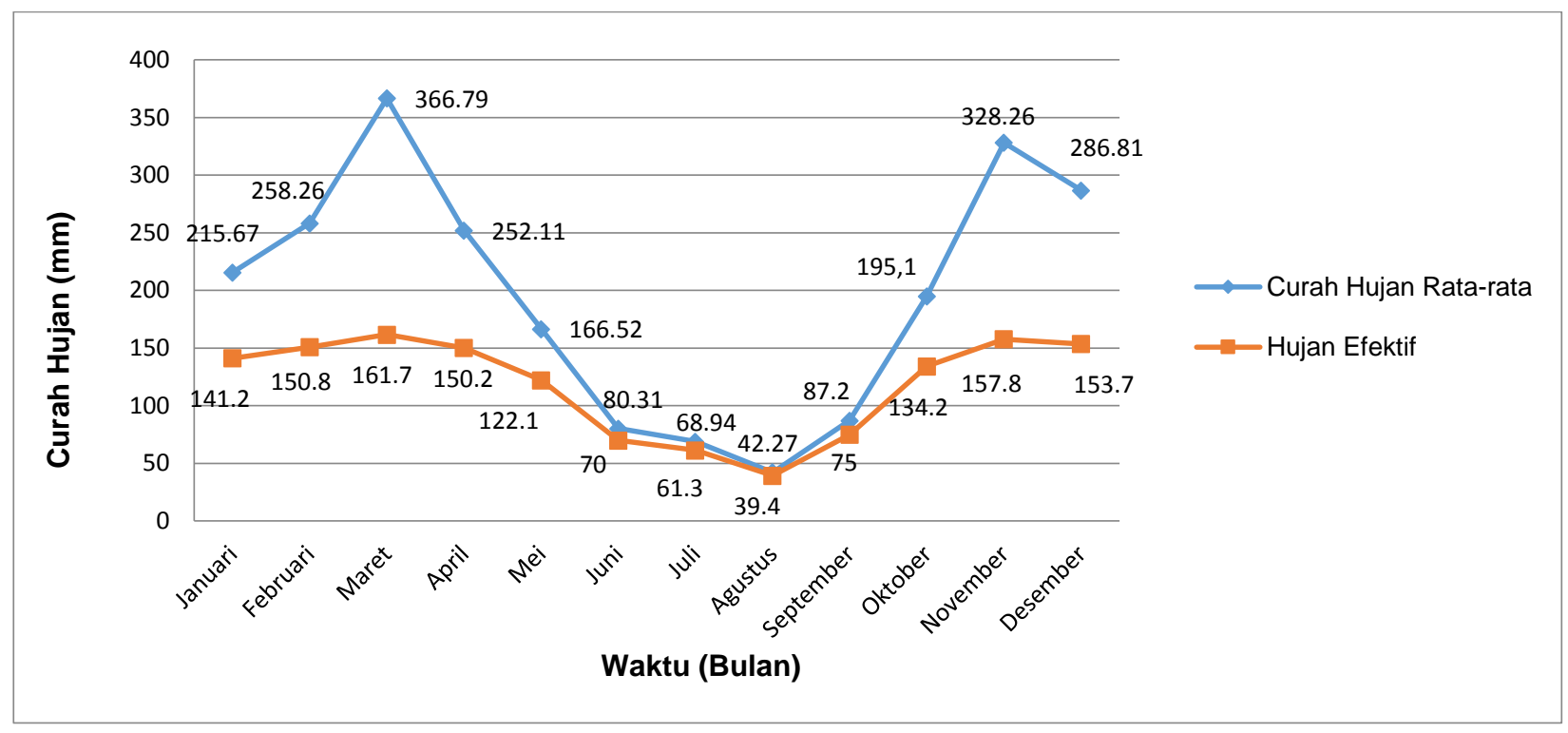

Gambar 3. Curah Hujan dan Hujan Efektif 10 Tahun Terakhir (2008-2017) Stasiun LAPAN Sumedang

\section{Analisis Sifat Fisika Tanah}

Sifat fisika tanah merupakan salah satu faktor yang berpengaruh terhadap pengangkutan udara, panas air dan bahan terlarut dalam tanah.

Tabel 1. Analsis Sifat Fisika Tanah

\begin{tabular}{lc}
\hline \multicolumn{1}{c}{ Parameter } & Keterangan \\
\hline Tempat & Cimasuk \\
Bulk Density (gr/cc) & 1,02 \\
Permeabilitas (cm/jam) & 19,70 \\
Kapasitas Lapang (\% volume) & 40,1 \\
Titik Layu Permanen (\% volume) & 28,8 \\
Air Tersedia (\% volume) & 11,3 \\
\hline
\end{tabular}

Berdasakan Tabel 1, Cimasuk memiliki nilai bulk density 1,02 gr/cc. Bulk density merupakan ukuran kepadatan tanah yang mempengaruhi laju permeabilitas, karena semakin padat maka sulit air untuk menembus akar tanaman. Nilai permeabilitasnya adalah 19,70 cm/jam. Permeabilitas tanah merupakan kemampuan tanah tanah untuk meloloskan air dalam keadaan jenuh. Dari hasil tersebut juga menunjukkan kandungan air untuk kondisi kapasitas lapang adalah sebesar 40,1\% volume atau 401 $\mathrm{mm} / \mathrm{m}$ sedangkan nilai titik layu permanen adalah $28,8 \%$ volume atau $288 \mathrm{~mm} / \mathrm{m}$ sehingga kadar air tersedia sebesar $11,3 \%$ volume atau $113 \mathrm{~mm} / \mathrm{m}$. Kapasitas lapang merupakan keadaan tanah yang cukup lembab dan menunjukkan air terbanyak yang dapat tertahan oleh tanah terhadapt gaya gravitasi. Nilai kapasitas lapang didapatkan dari pengujian kadar air pada $\mathrm{pF} 2,54$, sedangkan pengujian titik layu permanen dilakukan pada pF 4,2.

Konsep penyediaan air dalam jumlah yang cukup dan seimbang dalam pertumbuhan tanaman adalah kandungan air antara kapasitas lapang dan titik layu permanen atau yang disebut dengan air tersedia(Liang, Liakos, Wendroth, \& Vellidis, 2016; Stirzaker et al., 2016). Kapasitas lapang itu merupakan kandungan air dalam tanah, biasanya dapat dicapai 2 sampai 3 hari setelah saat kejadian hujan atau pembasahan ketika proses drainase berhenti. Kandungan air tanah pada kondisi kapasaitas lapang sangat dipengaruhi oleh beberapa faktor, diantaranya tekstur tanah, kandungan air tanah awal, dan kedalaman permukaan air tanah. Titik layu permanen merupakan kandungan air tanah dimana tanaman itu sepenuhnya mengalami kondisi layu dan akhirnya akan mati, karena tidak mampu lagi mengembalikan fungsi turgor dan aktivitas biologisnya. Dwiratna menyatakan bahwa perlakuan kelembaban tanah, ternyata semakin rendah tingkat kelembaban tanah saat pemberiaan air, jumlah air pemberian air akan semakin sedikit (Sophia Dwiratna et al., 2016).

\section{Kebutuhan Air Tanaman}

Air merupakan bagian terbesar dari jaringan tumbuhtumbuhan. Unsur hara yang diperlukan oleh tanaman harus dilarutkan menggunakan air sebelum diserap oleh tanaman dan disebarkn ke seluruh bagian tanaman tersebut. Ketersediaan air juga akan berperan penting dalam proses metabolisme tanaman. Kebutuhan air tanaman merupakan pemberian air yang hilang akibat adanya evapotraspirasi tanaman (ETc), sehingga dapat dikatan nilai kebutuhan air tanaman yang diberikan sama dengan jumlah dari nilai evapotranspirasi tanaman. Kebutuhan air tanaman dalam software Cropwat 8.0 dihitung setiap 10 harian (dasarian) yang besarnya berbeda-beda tergantung besarnya nilai evapotranspirasi tanaman (ETc) pada setiap dekade. Kebutuhan air juga bergantung kepada jumlah curah hujan yang turun, ketika memasuki musim penghujan maka kebutuhan air irigasinya akan lebih sedikit. Berdasarkan data menurut Tabel 3, nilai kebutuhan air tanaman (ETc) adalah sebesar $1088,7 \mathrm{~mm}$ sedangkan nilai kebutuhan irigasi nya adalah sebesar $103 \mathrm{~mm}$.

\section{Penjadwalan Irigasi}

Penjadwalan irigasi ini akan terbentuk apabila beberapa faktor pada gambar sub-bab telah dianalisis hingga mendapatkan nilai kebutuhan air tanaman dan kebutuhan air irigasi. Pengelolaan irigasi yang tepat mengharuskan petani untuk mengetahui kebutuhan irigasi melalui pengukuran berbagai parameter. Penentuan interval irigasi 
didasarkan pada dua pendekatan yaitu pengukuran tanah dan pemantauan terhadap tanaman. Menurut Perwitasari, et, al. (2016) terdapat dua pertanyaan umum dalam pengelolaan dan penjadwalan irigasi, yaitu: "Kapan petani harus mengairi?" dan "Berapa banyak air irigasi yang diberikan?" Informasi tersebut dapat digunakan untuk memperkirakan waktu pemberian irigasi sebelum tanaman mengalami cekaman air. Penelitian ini menggunakan option
4 yaitu interval at fixed interval per stage dimana irigasi diberikan dengan selang interval 3 dan 4 hari pada setiap pertumbuhan. Pilihan yang berkaitan dengan berapa banyak air yang diberikan setiap kali pemberian digunakan option 2 (refill soil to field capacity) dimana jumlah air irigasi setiap diberikan adalah konstan hingga mencapai batas kapasitas lapang tanah.

Tabel 2. Kebutuhan Air Irigasi

\begin{tabular}{|c|c|c|c|c|c|c|c|}
\hline Bulan & Dekade & Fase & Kc & ETc (mm/hari) & ETc (mm/dekade) & $\begin{array}{l}\text { Hujan Efektif } \\
\text { (mm/dekade) }\end{array}$ & $\begin{array}{c}\text { Kebutuhan Irigas } \\
\text { (mm/dekade) }\end{array}$ \\
\hline Okt & 1 & Init & 1.00 & 4.10 & 41.0 & 39.3 & 1.7 \\
\hline Okt & 2 & Init & 1.00 & 4.07 & 40.7 & 46.4 & 0.0 \\
\hline Okt & 3 & Deve & 1.00 & 3.86 & 42.5 & 48.5 & 0.0 \\
\hline Nov & 1 & Deve & 1.09 & 3.97 & 39.7 & 50.9 & 0.0 \\
\hline Nov & 2 & Deve & 1.22 & 4.20 & 42.0 & 53.9 & 0.0 \\
\hline Nov & 3 & Deve & 1.35 & 4.62 & 46.2 & 53.0 & 0.0 \\
\hline Des & 1 & Deve & 1.49 & 5.04 & 50.4 & 51.9 & 0.0 \\
\hline Des & 2 & Deve & 1.62 & 5.45 & 54.5 & 51.6 & 2.9 \\
\hline Des & 3 & Mid & 1.76 & 5.91 & 65.0 & 50.1 & 14.9 \\
\hline Jan & 1 & Mid & 1.80 & 6.05 & 60.5 & 47.8 & 12.7 \\
\hline Jan & 2 & Mid & 1.80 & 6.05 & 60.5 & 46.1 & 14.4 \\
\hline Jan & 3 & Mid & 1.80 & 5.96 & 65.5 & 47.5 & 18.1 \\
\hline Feb & 1 & Mid & 1.80 & 5.87 & 58.7 & 49.2 & 9.5 \\
\hline Feb & 2 & Mid & 1.80 & 5.78 & 57.8 & 50.3 & 7.5 \\
\hline Feb & 3 & Mid & 1.80 & 5.94 & 47.5 & 51.5 & 0.0 \\
\hline Mar & 1 & Late & 1.80 & 6.10 & 61.0 & 53.4 & 7.6 \\
\hline Mar & 2 & Late & 1.73 & 6.04 & 60.4 & 54.9 & 5.5 \\
\hline Mar & 3 & Late & 1.63 & 5.59 & 61.5 & 53.3 & 8.2 \\
\hline Apr & 1 & Late & 1.52 & 5.15 & 51.5 & 51.8 & 0.0 \\
\hline Apr & 2 & Late & 1.42 & 4.74 & 47.4 & 50.8 & 0.0 \\
\hline Apr & 3 & Late & 1.33 & 4.33 & 34.7 & 38.0 & 0.0 \\
\hline Total & & & & & 1088.7 & 1039.9 & 103.0 \\
\hline
\end{tabular}

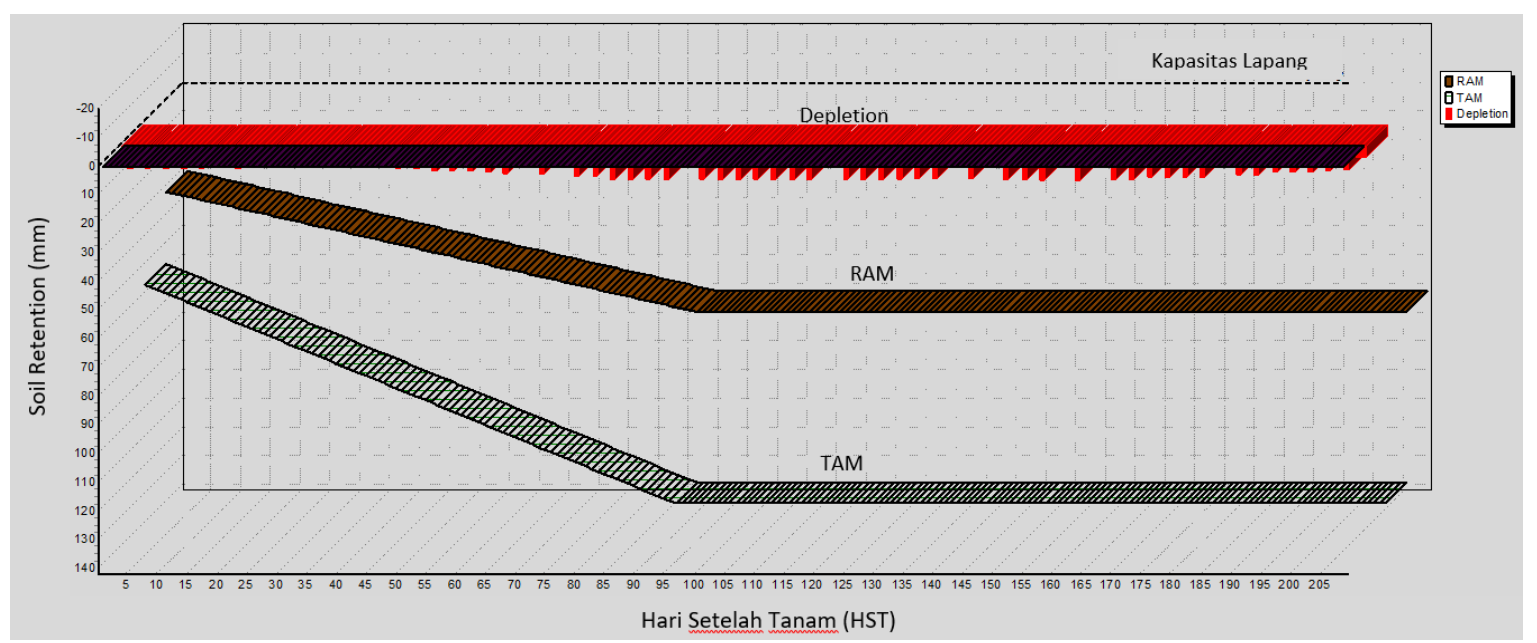

Gambar 4. Tampilan Grafik Penjadwalan Irigasi dari Cropwat 8.0 dengan interval 3 hari sekali

Metode penjadwalan irigasi umumnya didasarkan pada dua metode pendekatan, yaitu pengukuran tanah dan pemantauan tanah(Sophia Dwiratna \& Nurpilihan, 2016). Dalam penjadwalan irigasi ini diperlukan pengetahuan mengenai kadar air tanah yang tersedia untuk suatu tanaman. Mengetahui kadar air tanah yang tersedia, maka dapat memperkirakan tanggal awal dimana air harus diberikan sebelum cekaman air terjadi. Pengunaan interval 3 hari dan 4 hari dikarenakan bahwa untuk tanaman semusim, batasan maksimum interval irigasi adalah 5 hari pada kondisi kemarau, karena kemampuan tanah menyuplai air hanya sampai 2 hari dan setelah itu tanaman akan mati (Sophia Dwiratna, Bafdal, Asdak, \& Carsono, 2018b).

Berdasarkan Gambar 4 dapat dilihat bahwa besarnya kebutuhan air irigasi pada setiap fase pertumbuhan dan pada setiap interval 3 hari tersebut berbeda-beda. Jumlah total kebutuhan air irigasi selama budidaya Talas Pratama yaitu sebesar 983.840 liter. Kebutuhan air irigasi untuk tanaman memperlihatkan kondisi tanaman, curah hujan dan fase pertumbuhan. Pada kondisi dimana tanah masih dalam keadaan lembab, maka kebutuhan air lebih sedikit dibandingkan fase yang lainnya. Kebutuhan air akan lebih tinggi ketika tanaman berada pada fase pertengahan (mid 
stage) karena tanaman memasuki fase pembungaan (Sophia Dwiratna et al., 2018a).

Gambar 6 menunjukkan bahwa pada interval 4 hari pun nilai kebutuhan air berbeda-beda tergantung fase dan kondisi air dalam tanah. Hasil total dari irigasi iterval 4 hari adalah sebesar 851.520 liter selama dalam proses budidaya. Ketika nilai curah hujan tinggi maka kebutuhan air irigasi akan semakin rendah, karena hujan akan mempengaruhi ketersediaan air dalam tanah Selisih jumlah total dari kebutuhan air irigasi pada kedua interval adalah sebesar 132.320 liter. Efisiensi irigasi yang digunakan adalah sebesar $70 \%$ dikarenakan di lahan penelitiaan proses pemberian airnya menggunakan sistem irigasi permukaan, sehingga memungkinkan adanya air yang terbuang tidak termanfaatkan oleh tanaman. Faktor tersebut diantaranya, proses evapotranspirasi, air limpasan dan perkolasi.

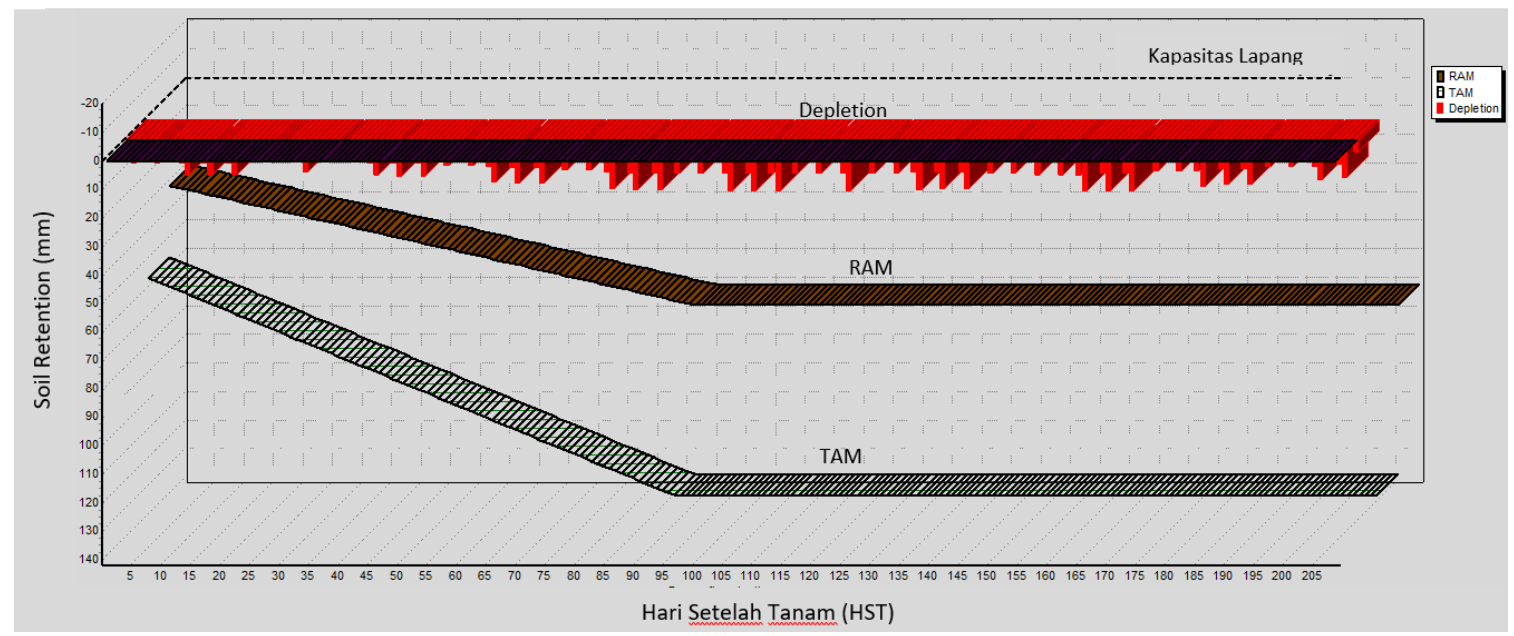

Gambar 6. Tampilan Grafik Penjadwalan Irigasi dari Cropwat 8.0 dengan interval 4 hari sekali

Berdasarkan Tabel 3. terlihat bahwa total irigasi kotor dan bersih irigasi dengan interval 3 hari lebih banyak dibandingkan dengan interval 4 hari, dikarenakan pemberian air lebih sering. Selisih irigasi kotornya adalah sebesar 165,2 mm sedangkan untuk irigasi bersihnya adalah sebesar $115,7 \mathrm{~mm}$. Nilai kebutuhan air irigasi actual dengan penggunaan air actual oleh tanaman keduanya memiliki nilai yang sama untuk kedua interval yaitu sebesar $1084,4 \mathrm{~mm}$, sehingga presentase efisiensi jadwal pemberian irigasi nya adalah $100 \%$. Total curah hujan yang sama tidak membuat nilai curah hujan efektifnya sama, nilai curah hujan efektif di interval 4 hari lebih tinggi dibandingkan dengan interval 3 hari dengan selisih sebesar $115,7 \mathrm{~mm}$. Presentase efisiensi hujan lebih tinggi untuk penjadwalan irigasi interval 4 hari yaitu sebesar $17,6 \%$ sedangkan unutk interval 3 hari adalah sebesar $11,5 \%$. Namun berbeda dengan kebutuhan irigasi aktual, bagi penjadwalan irigasi dengan interval 3 hari lebih tinggi $\mathrm{d}=$ yaitu sebesar $865,3 \mathrm{~mm}$ sedangkan interval 4 hari sebesar $749,7 \mathrm{~mm}$.

Tabel 3. Rekapitulasi Irigasi

\begin{tabular}{lll}
\hline \multicolumn{1}{c}{ Total } & \multicolumn{1}{c}{ Interval 3 } & \multicolumn{1}{c}{ Interval 4 } \\
\hline Total Irigasi Kotor & $1230,0 \mathrm{~mm}$ & $1064,8 \mathrm{~mm}$ \\
Total Irigasi Bersih & $861,0 \mathrm{~mm}$ & $745,3 \mathrm{~mm}$ \\
Total kehilangan Irigasi & 0 & 0 \\
Penggunaan Air Aktual oleh Tanaman & $1084,4 \mathrm{~mm}$ & $1084,4 \mathrm{~mm}$ \\
Kebutuhan Air irigasi Aktual & $1084,4 \mathrm{~mm}$ & $1084,4 \mathrm{~mm}$ \\
Efesiensi Jadwal Pemberian Irigasi & $100,0 \%$ & $100,0 \%$ \\
Defesiasi Jadwal Pemberian Irigasi & 0 & 0 \\
Total Curah Hujan & $1903,0 \mathrm{~mm}$ & $1903,0 \mathrm{~mm}$ \\
Curah Hujan Efektif & $219,0 \mathrm{~mm}$ & $334,7 \mathrm{~mm}$ \\
Total Kehilangan Hujan & $1684,0 \mathrm{~mm}$ & $1568,3 \mathrm{~mm}$ \\
Defisit Panen & $4,3 \mathrm{~mm}$ & $4,3 \mathrm{~mm}$ \\
Kebutuhan Irigasi Aktual & $865,3 \mathrm{~mm}$ & $749,7 \mathrm{~mm}$ \\
Efesiensi Hujan & $11,5 \%$ & $17,6 \%$ \\
\hline
\end{tabular}

\section{KESIMPULAN}

Berdasarkan hasil yang diperoleh maka dapat disimpulkan bahwa dalam budidaya Talas Pratama di Waaida Farm memiliki kebutuhan air sebesar 1088,7 mm dengan kebutuhan air irigasi adalah sebesar $103 \mathrm{~mm}$. Kebutuhan air irigasi pada budidaya Talas Pratama dengan sistem irigasi permukaan untuk luas lahan $800 \mathrm{~m}^{2}$ interval 4 hari adalah sebesar 851.520 liter dan untuk interval 3 sebesar 983.840 liter, kebutuhan air tersebut dapat terpenuhi dengan embung yang tersedia dengan volume tamungan air sebanyak 56 meter kubik. 


\section{DAFTA PUSTAKA}

Abdalla, S. A., Mustafa, M. A., \& Fadlallmula, M. (2008). Use of Supplementary Irrigation for Improvement of Growth and Yield of Sorghum \{ Sorghum bicolor ( L .) Monech \} in North Darfur State (p. 15pp). p. 15pp.

Abdalla, S. A., Mustafa, M. A., Fadlallmula, M., Abdulkader, N. A., Aegerter, B., Ahmad, M., ... Yuehong, Z. (2015). Irrigation Scheduling: The Water Balance Approach. Agricultural Water Management, 4(1), 1-6. https://doi.org/10.1016/j.crm.2014.04.001

Allen, R. G., Pereira, L. S., Raes, D., \& Smith, M. (1998). Crop evapotranspiration: Guidelines for computing crop requirements. Irrigation and Drainage Paper No. 56, FAO, (56), https://doi.org/10.1016/j.eja.2010.12.001

Dwiratna, S., Bafdal, N., Asdak, C., \& Carsono, N. (2018). Study of runoff farming system to improve dryland cropping index in Indonesia. International Journal on Advanced Science, Engineering and Information Technology, $8(2)$. https://doi.org/10.18517/ijaseit.8.2.3268

Dwiratna, Sophia, Bafdal, N., Asdak, C., \& Carsono, N. (2018a). Study of Runoff Farming System to Improve Dryland Cropping Index in Indonesia. International Journal of Advanced Science, Engineering, Information Technology, 8(2), 390-396.

Dwiratna, Sophia, Bafdal, N., Asdak, C., \& Carsono, N. (2018b). Study of Runoff Farming System to Improve Dryland Cropping Index in Indonesia. International Journal on Advanced Science, Engineering and Information Technology, 8(2). https://doi.org/http://dx.doi.org/10.18517/ijaseit.8.2.326 8

Dwiratna, Sophia, Nawawi, G., \& Asdak, C. (2013). Analisis Curah Hujan dan Aplikasinya dalam Penetapan Pola Tanam Pertanian Lahan Kering di Kabupaten Bandung. Jurnal Bionatura, 15(1), 29-34.

Dwiratna, Sophia, \& Nurpilihan, B. (2016). Irrigation Scheduling on Runoff Harvesting for Dryland Farming. In L. Sutiarso \& H. Amanah (Eds.), The 2nd International Symposium on Agricultural and Biosystem Engineering (p. A01.1-A01.8). Yogyakarta, Indonesia.

Dwiratna, Sophia, Suryadi, E., \& Kamaratih, K. D. (2016). Optimasi Pola Tanam Pada Lahan Sawah Tadah Hujan Di Kecamatan Cimanggung Kabupaten Sumedang. Jurnal Teknotan, 10(1), 37-45.

Erkossa, T., Haileslassie, A., \& MacAlister, C. (2014). Enhancing farming system water productivity through alternative land use and water management in vertisol areas of Ethiopian Blue Nile Basin (Abay). Agricultural Water Management, 132, 120-128. https://doi.org/10.1016/j.agwat.2013.10.007

Fuadi, N. A., Tarigan, S. D., Barat, J., \& Barat, J. (2016). Kajian Kebutuhan Air dan Produktivitas Air Padi Sawah dengan Sistem Pemberian Air Secara SRI dan Konvensional Menggunakan Irigasi Pipa. Jurnal Irigasi, 11(1), 23-32.

Iskandar, H. (2018). Pengolahan Talas (Colocasia Esculenta L., Schott) Menjadi Keripik Menggunakan Alat Vacum Frying Dengan Variasi Waktu. Jurnal Pendidikan Teknologi Pertanian, 4, 29-42.

Liang, X., Liakos, V., Wendroth, O., \& Vellidis, G. (2016). Scheduling irrigation using an approach based on the van Genuchten model. Agricultural Water Management, 176, 170-179. https://doi.org/10.1016/j.agwat.2016.05.030

Savva, A. P., \& Frenken, K. (2002). Irrigatin Manual Module 4. Crop Water Requirements and Irrigation Scheduling. Harare, Zimbabwe: Food and Agriculture Organization
(FAO).

Stirzaker, R. J., Maeko, T. C., Annandale, J. G., Steyn, J. M., Adhanom, G. T., \& Mpuisang, T. (2016). Scheduling irrigation from wetting front depth. Agricultural Water Management. https://doi.org/10.1016/j.agwat.2016.06.024

Sudomo, A., \& Hani, A. (2014). Produktivitas talas (Colocasia esculenta L., Schott) Di Bawah Tiga Jenis Tegakan dengan Sistem Agroforestro di Lahan Hutan Rakyat. Jurnal IImu Kehutanan, 8(2), 100-107.

Suryadi, E., Kendarto, D. R., Sistanto, B. A., Ruswandi, D., \& Dwiratna, S. (2018). A Study of Crop Water Needs and Land Suitability in the Monoculture System and Plant Intercropping in Arjasari. International Journal of Advanced Science, Engineering, Information Technology, 8(2), 554-560.

Welde, K., \& Gebremariam, H. L. (2016). Effect of different furrow and plant spacing on yield and water use efficiency of maize. Agricultural Water Management, 177 , 215-220. https://doi.org/10.1016/j.agwat.2016.07.026 
TEKNOTAN, Vol. 13, No. 2, Desember 2019

Halaman ini dikosongkan 